\title{
Administrative and Sociological Variables As Correlates of Athletes' Performance in Nigeria School Sports Federation in North-Central States, Nigeria
}

\author{
Falaye Elijah Kayode*, Ajadi Memunat Tunrayo, Abdulraheem Yinusa Owolabi, A. A. Adesoye \\ Department of Human Kinetics Education, University of Ilorin, Kwara State, Nigeria \\ *Coresponding Author: sampayoo2014@gmail.com
}

\begin{abstract}
This study examined administrative and sociological variables as correlates of athletes performance in Nigeria School Sports Federation in North-Central States, Nigeria. The objectives of the study were to: (i) determine the relationship between parental influence and athletes performance in NSSF competition (ii) ascertain the relationship between funding and athletes performance in NSSF competition. Descriptive design of correlation type was adopted for the study. The population for the study comprised sports officers, coaches and NSSF coordinators. Purposive and proportionate random sampling technique were used to select 585 respondents. Validated researcher designed structured questionnaire which was tested for reliability with a reliability coefficient of 0.80 was used for data collection. Pearson Product Moment Correlation were used for data analysis at 0.05 alpha level. The result of the findings: there was a significant relationship between parental influence and athletes performance in NSSF competition, there was a significant relationship between funding and athletes performance in NSSF competition. The study concluded that sports officers, coaches and NSSF coordinators contributed to brilliant performance of athletes in Nigeria school sports federation in North-central states Nigeria. The implication is that sports officers, NSSF coordinators and coaches play critical roles in achieving excellent performance of athletes in school sports competition.
\end{abstract}

\author{
ARTICLE HISTORY \\ Received 2021-12-05 \\ Accepted 2022-01-28

\section{KEYWORDS} \\ Administrative \\ Athletes Performance \\ Sociological \\ Variable
}

\section{INTRODUCTION}

School sport is an institutionalized competition that involves vigorous physical exertion or the use of relative complex physical skills by individual whose participation is motivated by a combination of intrinsic satisfaction associated with the activity itself and external rewards which can be earned through athletic performance (Orunaboka \& Ihekweme, 2011). Orunaboka and Nathan (2017) observed that sports play prominent role in the life of a nation both economically or politically. The successful organization and administration of a sports programme in any school is an indication of a nation's human potentials and effective management of such potentials in term of organizing competition to discover talents among school children. In Nigeria with a population 
of over 150 million people, there is no doubt that there are gifted young men and women in the area of sports compared to countries of the world. Jain (2015) stressed that the discovery of talented young athletes and development of athletes from school sports programmes in Nigeria have not reached its peak. This is as a result of the challenges confronting the nation. These ranges from socio-economic, psychological and gender related problems. School sports programme is designed in such a way that opportunities are provided for secondary school athletes to participate in various sporting activities which provide a wide range of abilities to perform excellently.

Adesoye (2012) affirmed that a desirable sports programme can be effectively managed or implemented in our schools and other establishment, if the funds released in running the affairs of sports are well-managed by the sports administrators. However sports administrators in the organization of school sports programmes in North Central States Nigeria are, school principals, N.S.S.F coordinators, coaches, sports officers, Ministry of Youth and Sports, Ministry of Education, Sports Council and Members of Sports Committees. Ajadi, Babadare, Ibraheem and Adesoye (2014) pointed out that performance is usually regarded as an aggregation of individual result such as performance over a month or season of competition as opposed to single or isolated activity. Athletes performance included assessment of a particular result. The performance of any athlete depends largely on the type of motivational measure put in place by sports manager and sport facilities available for training within a period of time. sports performance of an athlete can be measured through the outcome of result obtained in a competition or the amount of medal won in a tournament either by a team or by a single athlete while performance in sports is the higher level attained or the peak of an athlete as a result of his/her degree of training. Also winning is an important aspect of sports and can be kept in perspective when athletes recognizes that the process of striving to win can bring out the best in their performance, commitment in addition to their moral development due to effective sports management functions (Dorfman 2005, Joy \& Okou 2018).

Sociological variables such as age, gender, ordinal position, parents, sports values, belief of people towards sports, location of students hall, sports facilities and equipment, provision of accommodation for students especially during competition, provision of adequate sports outfits and mode of dressing often determine athletes performance in school sports competitions. (Abubakar, Umar, Akitoye \& Chom 2018). Furthermore, family, socio-economic background of the parents, age, religion, gender, geographical factors such as river-rine area, ethnicity social stratification and other social factors are factors that encourage children to participate in sports parents shape the behaviour of the young one's in relation to their social goals as well as the overall climate of sporting child especially in competitive environment such as sports center in school environment (Parkings, 2017). The Nigeria School Sports Federation (NSSF) is a body that was set up by the Federal Government in 1976 under the supervision of both the National Sports Commission and Federal Ministry of Education. The federation comprises of representatives of participating schools, National Sports Commission, Ministry of Education, Sports Councils, Ministry of Sports, Association of Sports Officers (ASSPO) and school management boards. This body was saddle with the responsibility of organizing different sports festivals involving categories of secondary school education in the country. Secondary schools sports competition started in 1933 and it was called Hussey shield. The maiden edition took place in Kano in 1934. 
Ibrahim (2013) observed that the Nigeria School Sports Federation is charged with the responsibility of organizing and administering sports at primary and post primary institutions (Basic and secondary) in Nigeria. The body is also an affiliate of the International School Sports Federation (ISF) with its secretariat in Belgium. Ibrahim (2013) pointed out that from 1998 to 2008 N.S.S.F held national secondary and primary schools competitions as separate games. In 2008 the different games were merged and the fusion gave birth to the first National School Sports Festival tagged "Lagos 2008". Events held in three categories, primary (under 12), junior secondary (under15) and senior secondary (under 17). Since then the festival has become an annual gathering of young athletes, providing a platform for school boys and girls to show-case their talent and blossom across class. Through the support and sponsor of the host state government the National School Sports Festival was held from 2008 to 2012.

However, it is observed that, the decline in athletes performance among the states in the North central geo-political zone of Nigeria in annual all secondary schools milo basketball championship and National Shell Football Competition in the last 5 years may be linked to ineffective sports management functions by the N.S.S.F state coordinators in term of discharging their responsibility by providing the needs of this young athletes. The decline in the athletes performance in the last five years can be linked to both administrative and sociological variables such as parental influence because parents plays a significant role in determine the level of participation of students in sports. The financing of education programmes is on the increase every year and sports programmes are no exception. Akintunde (2001) observed that one of the major administrative problem facing school sports programme is finance. He further highlighted three ways of financing school sports programmes. The first method is the idea of the school taking the total responsibilities through fund raising programmes through the philanthropist and also school fees.

The concept of culture is very fundamental in understanding human and social behaviour of an individual. Culture is the way people live that consists of a system of ideals, values, beliefs, knowledge and customs transmitted from generation to generation within a social group (Nigeria Educational Research and Development Council, 2009). The emphasis of culture and sports promotion cannot be ignored because culture and sports are products of social interaction. Culture is that of total repertories of human action and its product which are socially transmitted. The author further stressed that sports in recent times or during the primitive age cannot be separated from culture because culture determines the desirable activities in any society.

According to Parkings (2017) participating father in sports would surely influence his children to participate in sports while non-participating parents in sports will always discourage their children from participating in sports. Parental influence often determine the level of participation of school children in an organized school sports competition. Most parents usually discourage children from participating in sports due to the fact that they want their children to become lawyer, medical doctors, accountants e.t.c. after their studies. Life starts from home and for an athlete to excel he/she needs the supports of the parents. Mohammed (2014) stressed that the moral support and encouragement plus enabling environment provided by the home (parents) can make a difference as the athletes strives hard to attain highest level of performance in a competitions 
presence of parents in the sporting arena on the day of competition can go along way to motivate athletes performance as not to let his/her parents down.

\section{METHODS}

A descriptive research design of correlational type was employed for this study. This research design is considered appropriate for the study because it involved the collection of two sets of data, one of which was retrospective with a view to determine the relationship the dependent variables and independent variables. The population for this study comprised all sports officers, coaches and N.S.S.F state cordinators with approximately 756 respondents. The sampling techniques use for this study were purposive, proportionate and random sampling techniques. Purposive sampling technique was used to select 44 state representative of N.S.S.F state cordinators and purposively 14 coaches were sampled while proportionate sampling techniques used to select $80 \%$ of sports officer across the seven (7) states in the study area, randomly 553 sports officers were sampled. In all 585 respondents were sample for this study. Researchers structured questionnaires was used. The instrument was validated and tested for reliability using Pearson Product Moment Correlation (PPMC). A correlation co efficiency of 0.80 was obtained. The administration of the questionnaire was done by the researchers and three trained research assistants. The data collected were analysed using inferential statistics of Pearson Product Moment Correlation through Statistical Package for Social Science to test the formulated hypotheses set for the study at 0.05 alpha level.

\section{RESULTS AND DISCUSSION}

Research Question 1: What is the attitude of parents to students' participation in Nigeria school sports federation competitions?

Table 1. Percentage of Attitudes of Parents to Students' Participation in Nigeria School Sports Federation Competitions

\begin{tabular}{|c|c|c|}
\hline Attitude of Parents & Frequency & Percentage (\%) \\
\hline Negative & 234 & 42.2 \\
\hline Positive & 351 & 57.8 \\
\hline Total & 585 & 100.0 \\
\hline Mean $=13.13$ & & \\
\hline
\end{tabular}

Table 1 reveals the attitude of parents towards students' participation in sports 234(42.2\%) had negative attitude while $351(57.8 \%)$ had positive attitude. This table also reveals that parents had the mean score of 13.13 which implies that parents had a positive attitude towards students' participation in sports.

Research Question 2: What are the social and cultural factors affecting students' participation in Nigeria school sports federation competition?

Table 2 indicates that "cultural belief of a society often contributes to athletes" performance. Cultural belief the first socio-cultural factor affecting students' participation in Nigeria school sports federation competition, had the mean score of 2.3225, standard deviation of 0.7537 and ranked first. 
Table 2. Mean, SD and Ranking of Socio-cultural factors affecting students' participation in Nigeria school sports federation competition

\begin{tabular}{|c|c|c|c|c|c|}
\hline $\mathrm{S} / \mathrm{N}$ & Socio-cultural factors & $\mathrm{N}$ & Mean & Std. Dev. & Rank \\
\hline 1. & $\begin{array}{l}\text { Cultural belief of a society often } \\
\text { contributes to athletes' performance }\end{array}$ & 585 & 2.3225 & .75437 & $1^{\text {st }}$ \\
\hline 2. & $\begin{array}{l}\text { Socio-cultural value is one of the } \\
\text { measures used to determine athletes' } \\
\text { performance }\end{array}$ & 585 & 2.30009 & .75853 & $2^{\text {nd }}$ \\
\hline 3. & $\begin{array}{l}\text { Cultural belief makes school athletes to } \\
\text { be conscious of participating in } \\
\text { competitive sports which often } \\
\text { enhance their performance }\end{array}$ & 585 & 2.2432 & .75305 & $3^{\text {rd }}$ \\
\hline 4. & $\begin{array}{l}\text { Culture can only be used to determine } \\
\text { the performance of secondary school } \\
\text { athletes }\end{array}$ & 585 & 2.20000 & .76804 & $5^{\text {th }}$ \\
\hline 5. & $\begin{array}{l}\text { Socio-cultural belief of people in terms } \\
\text { of their food intake often constitute } \\
\text { their performance }\end{array}$ & 585 & 2.2320 & .75211 & $4^{\text {th }}$ \\
\hline
\end{tabular}

"Socio-cultural value was one of the measures used to determine athletes' performance" with the mean score of 2.3009 and standard deviation of 0.75853 ranked second, while the third one way "cultural belief makes school athletes to be conscious of participating in competitive sports which often enhance their performance" with the means score of 2.2432 and the standard deviation of 0.75305 . "Culture can only be used to determine the performance of secondary school athletes" with the means score of 2.2000 and standard deviation of 0.76804 ranked $5^{\text {th }}$, and sociocultural belief of people in term of their food intake often constitute their performance with the mean score of 2.2320 and standard deviation of 0.75211 ranked $4^{\text {th }}$.

Research Question 3: What are the administrative challenges faced by schools in North Central Nigeria when participating in Nigeria school sports federation competition?

Table 3. Mean, SD and Ranking of Administrative challenges faced by athletes in North Central, Nigeria when participating in Nigeria school sports federation competition

\begin{tabular}{lllllc}
\hline S/N & \multicolumn{1}{c}{ Socio-cultural factors } & N & Mean & Std. Dev. & Rank \\
\hline $1 . \quad \begin{array}{l}\text { Beaurecratic process in approving } \\
\text { funds in the Ministry leads to } \\
\text { inadequate preparation of the teams }\end{array}$ & 41 & 3.3171 & 0.87861 & $1^{\text {st }}$ \\
$\begin{array}{l}\text { There is always a disagreement } \\
\text { between the school management and } \\
\text { the NSSF officers in the Ministry on } \\
\text { who is to finance the training }\end{array}$ & 41 & 3.2439 & 0.76748 & $2^{\text {nd }}$ \\
$\begin{array}{l}\text { programme of the team } \\
\text { There is always an administrative issue } \\
\text { on who is to bear the financial } \\
\text { implication of feeding and allowances } \\
\text { of athletes before and during } \\
\text { competition }\end{array}$ & 41 & 3.1707 & 1.68675 & $3^{\text {rd }}$ \\
\end{tabular}


Table 3 reveals that "beaurecratic process in approving funds in the Ministry leads to inadequate preparation of the teams" ranked first among the administrative challenges faced by schools in north central Nigeria when participating in Nigeria school sports federation competition with the mean score of 3.371 and standard deviation of 0.8786 . This was followed by "there is always a disagreement between the school management and the NSSF officers in the Ministry on who is to finance the training programme of the team" which ranked second with the mean score of 3.2439 and standard deviation of 0.76748 . The last administrative challenge was "there is always an administrative issue on who is to bear the financial implication of feeding and allowances of athletes before and during competition" with the mean score of 3.1707 and standard deviation of 1.68675 this ranked third.

Main Hypothesis: Administrative and sociological variables are not predictors of athletes' performance in Nigeria school sports federation competition in North Central states of Nigeria.

Table 4. Multiple Regression on Administrative and Sociological variables as Predictors of Athletes' Performance in Nigeria School Sports Federation Competition in North Central States, Nigeria

\begin{tabular}{llccccc}
\hline & Sum of Squares & $d f$ & $\begin{array}{c}\text { Mean } \\
\text { square }\end{array}$ & $F$ & Sig. & Inference \\
\hline Regression & 2969.405 & 2 & 1484.702 & & \\
Residual & 20708.675 & 582 & 37.516 & 39.575 & 0.000 & $\mathrm{~S}$ \\
Total & 23678.079 & 584 & & & & \\
\hline
\end{tabular}

Table 4 shows the calculated $\mathrm{f}$-value of regression table which is 39.575 with the critical $p$ value of 0.00 computed at 0.05 level of significance. Since the calculated $f$-value is greater than the critical p-value, the main hypothesis was hereby rejected. This implies that both administrative and sociological variables were good predictor variables that determine athletes performance in Nigeria school sports federation competitions in North Central states, Nigeria.

Table 5. Model Summary of the Independent Variables of Administrative and Sociological

\begin{tabular}{ccccccc}
\hline Model & & $\mathrm{R}$ & $\mathrm{R}$ & Adjusted R square & $\begin{array}{c}\text { Std. Error of } \\
\text { the estimate }\end{array}$ & $\begin{array}{c}\text { R square } \\
\text { change }\end{array}$ \\
\hline 1 & 0.354 & square & & 0.122 & 6.12501 & 0.125 \\
\hline
\end{tabular}

Table 5 indicates the contribution of the independent variables together. The R-square reveals 0.125 which implies that the two independent variables together were $12.5 \%$. To ascertain the contributions of each of the independent variable to the model (athletes performance in Nigeria school sports federation competition) Beta weight and the t-test were therefore, computed and outputs were reported in table 6 .

Table 6 reveals the Beta weights and t-values of the independent variables (sociological and administrative variables). It shows the contribution of the independent variables to the dependent variable. The result of Beta weights and $t$-values in table 6 indicates that both administrative and sociological variables were good predictors of athletes' performance in Nigeria school sports federation competitions in North Central states. 
Table 6. Contributions of each of the Independent Variables (Sociological and Administrative Variables) to the Dependent Variable (Athletes Performance)

\begin{tabular}{lccccc}
\hline \multicolumn{1}{c}{ Variables } & $\begin{array}{c}\text { Unstandardized } \\
\text { coefficients } \\
\text { B }\end{array}$ & $\begin{array}{c}\text { Std. } \\
\text { Error }\end{array}$ & $\begin{array}{c}\text { Standardized } \\
\text { coefficients } \\
\text { Beta }\end{array}$ & t-value & Sig. \\
\hline $\begin{array}{l}\text { (constant) } \\
\text { Sociological }\end{array}$ & $\begin{array}{c}22.296 \\
\text { variables }\end{array}$ & 1.594 & & 13.983 & .000 \\
$\begin{array}{l}\text { Administrative } \\
\text { Variables }\end{array}$ & 0.160 & 0.040 & .0177 & 4.0000 & .000 \\
\hline
\end{tabular}

The administrative variable contributes Beta weight of 0.238 and t-value of 5.372 , while sociological variable also contributes Beta weight of 0.177 and $t$-value of 4.000 . This implies that administrative variable is a better predictor of the athletes' performance compared to the sociological variable.

Hypothesis 1: There is no significant relationship between parental influence and athletes' performance in Nigeria school sports federation competitions in North Central states, Nigeria

Table 7. Revealed ' $r$ ' Analysis of Relationship between Parental Influence and Athletes' Performance in Nigeria School Sports Federation Competitions in North Central States, Nigeria

\begin{tabular}{|c|c|c|c|}
\hline Variables & & $\begin{array}{l}\text { Parental } \\
\text { influence }\end{array}$ & $\begin{array}{c}\text { Performance of } \\
\text { athletes }\end{array}$ \\
\hline \multirow[t]{3}{*}{ Parental influence } & $\begin{array}{l}\text { Pearson's } \\
\text { correlation }\end{array}$ & 1 & $0.263^{* *}$ \\
\hline & Sig. (2-tailed) & & 0.000 \\
\hline & $\mathrm{N}$ & 585 & 585 \\
\hline \multirow[t]{3}{*}{ Performance of athletes } & $\begin{array}{l}\text { Pearson's } \\
\text { correlation }\end{array}$ & $0.263^{* *}$ & 1 \\
\hline & Sig. (2-tailed) & 0.000 & \\
\hline & $\mathrm{N}$ & 585 & 585 \\
\hline
\end{tabular}

$\mathrm{P}<0.05$

Table 7 reveals the calculated $r$-value of 0.263 and critical p-value of 0.00 computed at critical $p$-value of 0.05 alpha level. Since the calculated $r$-value was greater than the critical $p$-value, the sub-hypothesis one was hereby rejected. This means that there was a significant relationship between parental influence and athletes performance in Nigeria school sports federation competitions in North Central states, Nigeria.

Hypothesis 2: There is no significant relationship between cultural belief and athletes' performance in Nigeria school sports federation competitions in North Central states, Nigeria

Table 8 indicates the calculated $r$-value of 0.221 against the critical $p$-value of 0.00 computed at 0.05 level of significance. Since the calculated $r$-value was greater than the critical $p$ value, the sub-hypothesis two was hereby rejected. This implies that there was a significant relationship between cultural belief and athletes performance in Nigeria school sports federation competitions in North Central Zone states, Nigeria. 
Table 8. Relationship between Cultural Belief and Athletes' Performance in Nigeria School Sports Federation Competitions in North Central States, Nigeria

\begin{tabular}{lccc}
\hline Variables & Cultural & $\begin{array}{c}\text { Performance of } \\
\text { belief }\end{array}$ & $0.221^{* *}$ \\
\hline Cultural belief & $\begin{array}{c}\text { Pearson's } \\
\text { correlation }\end{array}$ & 1 & 0.000 \\
& Sig. (2-tailed) & & 585 \\
Performance of athletes & $N$ & 585 & 1 \\
& $\begin{array}{c}\text { Pearson's } \\
\text { correlation }\end{array}$ & $0.221^{* *}$ & \\
& Sig. (2-tailed) & 0.000 & 585 \\
\hline
\end{tabular}

$\mathrm{P}<0.05$

Hypothesis 3: There is no significant relationship between sports funding and athletes' performance in Nigeria school sports federation competitions in North Central states, Nigeria

Table 9. Revealed ' $r$ ' Analysis of Relationship between Sports Funding and Athletes' Performance in Nigeria School Sports Federation Competitions in North Central States, Nigeria

\begin{tabular}{|c|c|c|c|}
\hline Variables & & Sports funding & $\begin{array}{c}\text { Performance of } \\
\text { athletes }\end{array}$ \\
\hline \multirow[t]{3}{*}{ Sports funding } & $\begin{array}{l}\text { Pearson's } \\
\text { correlation }\end{array}$ & 1 & $0.245^{\star \star}$ \\
\hline & Sig. (2-tailed) & & 0.000 \\
\hline & $\mathrm{N}$ & 585 & 585 \\
\hline \multirow[t]{3}{*}{ Performance of athletes } & $\begin{array}{l}\text { Pearson's } \\
\text { correlation }\end{array}$ & $0.245^{\star *}$ & 1 \\
\hline & Sig. (2-tailed) & 0.000 & \\
\hline & $\mathrm{N}$ & 585 & 585 \\
\hline
\end{tabular}

$\mathrm{P}<0.05$

Table 9 indicates the calculated $r$-value of 0.245 and critical $p$-value of 0.00 computed at 0.05 level of significance. Since the calculated $r$-value was greater than the critical $p$-value, the subhypothesis seven was hereby rejected. This means that there was a significant relationship between sports funding and athletes' performance in Nigeria school sports federation competitions in North Central Zone states, Nigeria.

Table 7 reveals that there was a significant relationship between parental influence and athletes performance in Nigeria school sports federation competitions in North Central states, Nigeria. This finding is in agreement with the findings of Mohammed (2014) who affirmed that the moral support and encouragement plus enabling environment provided by parents can make a difference as athletes strives hard to attain the highest level of performance in competitions. The presence of parents at the sporting arena on the day of competition can go a long way in making the athlete not letting his/her parents down by putting up a brilliant performance.

The result of tested hypothesis two in table 8 shows that there was a significant relationship between cultural belief and athletes performance in Nigeria school sports competitions in North Central states Nigeria. This result tallied with the view of Mohammed (2014) who stressed that 
culture is the total repertories of human actions and its product which are socially transmitted. Mohammed (2014) stressed that sports in recent times or during the primitive age cannot be separated from culture because cultural belief determines the desirable activities in any society. However, youths are being motivated to cultivate sports culture which often linger in mind throughout life time and for onward transmission of cultural belief to their off-springs and future generation participating in sports. Non-participation are usually influenced by several factors which are socio-cultural in nature, and among other things that are embedded in multidimensional issues depending on the norms in a given society. The finding from tested hypothesis seven in table 9 shows that there was a significant relationship between funding and athletes performance in Nigeria school sports federation competitions North Central states in Nigeria. This result supported the findings of Adesoye (2012) who affirmed that adequate provision of funds is not as important as the effective management of such funds for meaningful result as regards sports competitions in school. Fund is important and necessary for the provision of vital elements for the smooth running of sports programme management and planning to the extent at which they are effectively utilised in terms of releasing such funds to cater for the welfare of athletes which can brings about excellent performance.

\section{CONCLUSION}

The study concluded that sports officers, coaches and NSSF coordinators contributed to brilliant performance of athletes in Nigeria school sports federation in North-central states Nigeria. The implication is that sports officers, NSSF coordinators and coaches play critical roles in achieving excellent performance of athletes in school sports competition. The study recommended that NSSF coordinators and sports officers in North-Central States should provide facilities and increase funding of school sports competition to improve athletes' performance.

\section{REFERENCES}

Abubakar, A. A. (2018). Rejuvenating school sports programmes for peace and national development; Journal of Nigeria Association for Physical, Health Education, Sports and Dance 8(1) 57-63

Abubakar, Y.; Umar, M.; Akitoye, M. A. O. \& Chom, E. J. (2018). Strategies for resuscitating secondary school. Physical Education and sports for sustainable sports development in Nigeria; The role expectation of stakeholders; Journal of Nigeria Association for Physical, Health Education Sports and Dance 8(1) 145-150

Adesoye, A. A. (2003). Analysis of the effectiveness of sports programmes implementation in selected Nigeria universities; University of Ilorin Printing Press

Adesoye, A. A. (2012). Perceived limitations of female students participation in sports in institution of learning. A paper presented at WAUG University of Ilorin, Ilorin, Nigeria 77-80

Ajadi, M. T.; Ibraheem, T. O.; Adesoye, A. A. \& Babadare, A. (2014). Training and incentive as correlates of performance of athletes in sporting events in colleges of education Kwara State. Journal of Sports Psychology Association of Nigeria 9, 96-104

Akintunde, P. G. (2001). Administration and organization of physical and health education sports and recreation; Ibadan, Yew Printers 
Dorfman, H. H. (2005). Coaching the mental game, leadership philosophies and strategies for peak performance in sports and everyday life, Soweto, Durban press

Edim, M. E. \& Saba, I. A. (2014). Socio-cultural variables of religion and sports participation among secondary school students in Northern states of Nigeria. Journal of Emerging trends in Educational Research and Policy Studies 5(2) 232-235

Ibrahim, M. (2013). Background to national school sports federation. Welcoming address by the National President during the opening ceremony of $6^{\text {th }}$ edition of National School Sports Festival in Ilorin, Kwara State

Jain, D. (2015). Women development and the UN, A sixty year quest for equality and justice. Bloomington. Indian University Press 88-93

Joy, N. A. \& Okou, F. T. (2018). Comparative analysis of physical fitness indices of students in selected secondary schools in Akwa Ibom State; Journal of Nigeria Association for Physical, Health education, Sports and Dance, 8, (1) 178-188

Mohammed, S. M. (2014). Strategies for attaining and sustaining peak performance in sports and games. Journal of Sports Psychology Association of Nigeria 9, 89-95

Orunaboka, T. T. \& Ihekweme, C. (2011). Administrative factors influencing sports involvement of the Girl-child in school sports in Rivers State. Journal of Education and Practices (JEP) 2, (4) 54-58

Orunaboka, T. T. \& Ogulu, C. B. (2015). The impact of administration and sports programme implementation on the achievement of sports council at the 17th national sports Festival competition: a case study of rivers state sports council. Journal of Physical Education and Sport Management 6(5) 32-37

Orunaboka, T. T. \& Nathan, Y. K. (2007). Gender issues in physical education and sports. Nigeria Journal of Kinetics and Health Education Perspectives (JOKHEP) 1, (2) 74-87

Parkings, D.F. (2017). Parents making youth sports a positive experience of role model. Penn State extension press; llorin Journal of Health, Physical Education and Recreation (IJOPHER)Examples of reference entries: 